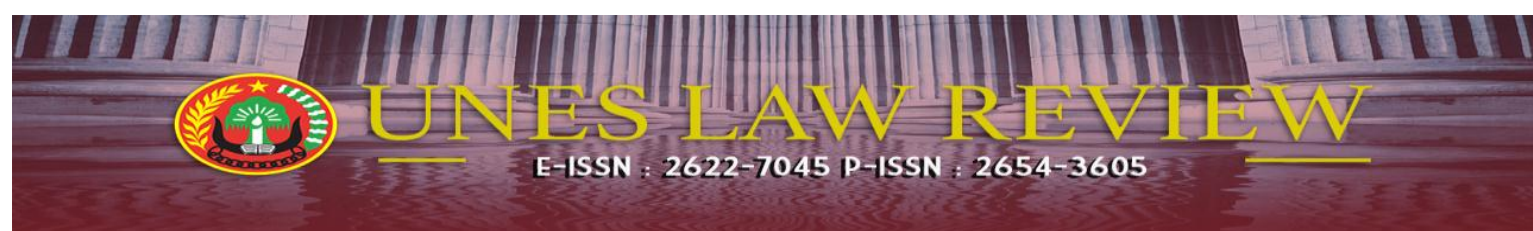

Email : uneslawreview@gmail.com Online : http://review-unes.com/index.php/law/index

Volume 1, Issue 3, Maret, 2019

E-ISSN : 2622-7045

P-ISSN : 2654-3605

\title{
IMPLEMENTASI MEDIASI PENAL DALAM PENYELESAIAN TINDAK PIDANA PENGRUSAKAN (Studi Pada Sat Reskrim Polres Solok)
}

\author{
${ }^{1}$ Hendri Nursin, ${ }^{2}$ Fitriati \\ ${ }^{1}$ Program Magister Ilmu Hukum, Universitas Ekasakti \\ Email: hendrinursin@gmail.com \\ ${ }^{2}$ Program Magister Ilmu Hukum, Universitas Ekasakti \\ Email: fitriati@review-unes.com
}

\begin{abstract}
Penal mediation is one of the means of resolving criminal acts that have often been carried out by law enforcement officials, especially at the level of investigations in the police as explained in the letter of the Chief of Police No: B / 3022 / XII / 2009 / SDEOPS, December 14, 2009 concerning Handling Case Through Alternative Dispute Resolution (ADR). Specifications in this study are descriptive analytical. The reason mediation model carried out by the Aro police station The likes of resolving criminal cases are mediation victim-offender models. This model places more emphasis on mediation between victims and perpetrators involving various parties who meet. The mediator can come from a formal official, independent mediator or combination. In this case the mediators involved were ninik mamak and local adat stakeholders and even the Kerapatan Adat Nagari (KAN). The obstacle encountered in the reasoning mediation of the Aro Suka police station is that there is no explicit regulation as a legal aspect governing reason mediation in the settlement of criminal cases, then the Police cannot fully act as mediators in the settlement of criminal cases through reasoning mediation, and there are still some people argues that all criminal cases can be carried out reason mediation or peace efforts between litigants. The effort that must be made is to encourage customary institutions in the nagari along with their traditional leaders to assist the National Police in resolving criminal cases whose source of problems starts from the issue of inheritance, inheritance, customary titles and so on.
\end{abstract}

Kata Kunci: Mediasi penal, Tindak Pidana, Penyidikan

\section{PENDAHULUAN}

Mediasi Penal merupakan dimensi baru yang dikaji dari aspek teoretis dan praktik. Dikaji dari dimensi praktik maka mediasi penal akan berkorelasi dengan pencapaian dunia peradilan. Seiring berjalannya waktu dimana semakin hari terjadi peningkatan jumlah volume perkara dengan segala bentuk maupun variasinya yang masuk ke pengadilan, sehingga konsekuensinya menjadi beban bagi pengadilan dalam memeriksa dan memutus perkara sesuai asas peradilan sederhana, cepat dan biaya ringan tanpa harus mengorbankan pencapaian tujuan peradilan 
yaitu kepastian hukum, kemanfaatan dan keadilan.

Mediasi di Kepolisian tidak dikenal dalam ketentuan undang-undang mengenai sistem peradilan pidana, yaitu UndangUndang Nomor 8 Tahun 1981 tentang Hukum Acara Pidana ("KUHAP”). Dalam UndangUndang Nomor 2 Tahun 2002 tentang Kepolisian Negara Republik Indonesia ("UU Kepolisian”) juga tidak diatur mengenai mediasi oleh pihak kepolisian. Akan tetapi, kita dapat melihat mengenai mediasi oleh polisi dalam tataran di bawah undang-undang, yaitu dalam Surat Kapolri No Pol: B/3022/XII/2009/SDEOPS tanggal 14 Desember 2009 tentang Penanganan Kasus Melalui Alternatif Dispute Resolution (ADR).Salah satu tindak pidana yang dapat dilakukan mediasi adalah tindak pidana pengrusakan.

Mediasi penal (penal mediation) sering juga disebut dengan berbagai istilah, antara lain : "mediation in criminal cases" atau "mediation in penal matters" yang dalam istilah Belanda disebut strafbemiddeling, dalam istilah Jer-man disebut "Der Außergerichtliche Tataus-gleich" (disingkat ATA) dan dalam istilah Perancis disebut "de mediation pénale". Karena mediasi penal terutama mempertemukan antara pelaku tindak pidana dengan korban, maka mediasi penal ini sering juga dikenal dengan istilah "Victim-Offender Medi-ation" (VOM), Täter-
Opfer-Ausgleich (TOA), atau Offender-victim Arrangement (OVA).

Mediasi penal merupakan salah satu bentuk alternatif penyelesaian sengketa di luar pengadilan (yang biasa dikenal dengan isti-lah ADR atau "Alternative Dispute Resolution"; ada pula yang menyebutnya "Apro-priate Dispute Resolution").

ADR pada umumnya digunakan di lingkungan kasus-kasus perdata, tidak untuk kasus-kasus pidana. Berdasarkan perundangundangan yang berlaku di Indonesia saat ini (hukum positif) pada prinsipnya kasus pidana tidak dapat diselesaikan di luar pengadilan, walaupun dalam hal-hal tertentu, dimungkinkan adanya penyelesaian kasus pidana di luar pengadilan.

Mediasi Penal dikenal dengan istilah mediation in criminal cases, mediation in penal matters, victim offenders mediation, offender victim arrangement (Inggris), strafbemiddeling (Belanda), der Au Bergerichtliche Tatausgleich (Jerman), de mediation penale (Perancis).

Dalam prakteknya di wilayah hukum Polres Solok, mediasi penal dalam penyelesaian tindak pidana pengrusakan sudah dilakukan dengan kesepakatan antara pihak korban dan pelaku pengrusakan yang difasilitasi oleh Kepolisian Sektor Gunung Talang, dimana pelaku melakukan pengrusakan atas sebuah rumah hak milik orang lain. Antara korban dan pelaku dilakukan penyelesaian kekeluargaan dengan 
melibatkan niniak mamak atau pemangku adat lainnya, sehingga diantara keduanya saling memaafkan dan tidak saling menuntut.

Berdasarkan latar belakang yang dipaparkan di atas, maka permasalahan yang akandibahas adalah implementasi penyelesaian perkara tindak pidana pengrusakan melalui mediasi penal di Polres Solok dan kendala dan upaya yang ditemui dalam penyelesaian perkara tindak pidana pengrusakan melalui mediasi penal di Polres Solok.

\section{METODE PENELITIAN}

Spesifikasi penelitian adalah deskriptif analisis,dengan metode pendekatan yuridis normatif sebagai pendekatan utama dan didukung dengan pendekatan yuridis empiris. Jenis data yang digunakan adalah data sekunder dan data primer. Data sekunderberupa bahan bahan hokum sedangkan data primer diperoleh dari studi lapangan di Polres Solok.

Teknik pengumpulan data pada data sekunder denganstudi dokumen dan studi kepustakaan data primer dilakukan dengan wawancara secara semi terstruktur. Data yang diperoleh kemudian dianalisa secara kualitatif.

\section{HASIL DAN PEMBAHASAN}

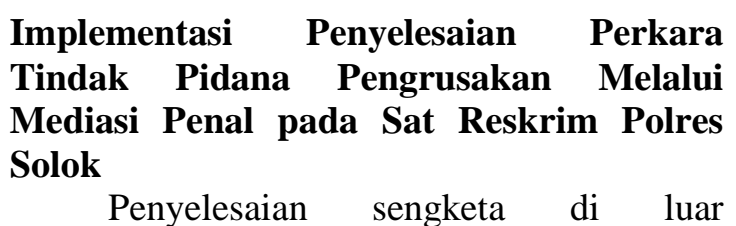
pengadilan hanya ada dalam sengketa perdata, namun dalam praktek sering juga kasus pidana diselesaikan di luar pengadilan melalui berbagai diskresi aparat penegak hukum atau melalui mekanisme musyawarah/perdamaian atau lembaga permaafan yang ada di dalam masyarakat (musyawarah keluarga; musyawarah desa; musyawarah adat dan sebagainya). Praktek penyelesaian perkara pidana di luar pengadilan selama ini tidak ada landasan hukum formalnya, sehingga sering terjadi suatu kasus yang secara informal telah ada penyelesaian damai (walaupun melalui mekanisme hukum adat), namun tetap saja diproses ke pengadilan sesuai hukum yang berlaku.

Keadilan dalam hukum pidana selama ini sudah dianggap ditegakkan apabila pelaku tindak pidana setelah melalui proses peradilan pidana dijatuhi sanksi sesuai dengan aturanaturan hukum pidananya. Pemikiran itu tersebut tidak terlepas dari dominasi paradigma Retributive Justice dalam pembentukan dan implementasi hukum pidana. Paradigma Retributive Justice melihat kejahatan sebagai persoalan antara negara dengan individu pelaku karena hukum yang ditetapkan oleh negara untuk menjaga ketertiban, ketentraman,dan keamanan kehidupan bermasyarakat telah dilanggar oleh pelaku.

Retributive Justice memandang bahwa wujud pertanggungjawaban pelaku harus bermuara pada penjatuhan sanksi pidana. Kerugian atau penderitaan korban dianggap 
sudah diimpaskan, dibayar atau dipulihkan oleh pelaku dengan menjalani dan menerima proses pemidanaan. Banyak pendapat mengemuka terkait dengan penjatuhan sanksi pidana, dikatakan bahwa substansi maupun prosedur penyelesaian tindak pidana melalui jalur hukum pidana yang selama ini dijalankan hampir tidak membawa manfaat apapun bagi pemulihan penderitaan korban. Selama ini sanksi pidana lebih merupakan "pembayaran atau penebusan" kesalahan pelaku kepada Negara daripada wujud pertanggung jawaban pelaku atas perbuatan jahatnya kepada korban. Padahal yang langsung mengalami penderitaan atau kerugian akibat tindak pidana itu adalah korbannya.

Perkembangan selanjutnya adalah timbulnyaupaya-upaya ke arah perbaikan perlakuan terhadap hak dan kepentingan korban tindak pidana. Salah satu upaya tersebut ialah mulai dikembangkannya paradigma Restorative Justice yang memandang kejahatan sebagai konflik antar individu dan pertanggung jawaban pelaku dirumuskan sebagai dampak pemahaman terhadap perbuatannya serta untuk membantu memutuskan mana yang paling baik bagi penyelesaian tindak pidana dengan mempertimbangkan penderitaan atau kerugian korban. Salah satu wujud implementasi Restorative Justice ialah melalui Mediasi Penal (penal mediation). Melalui proses mediasi penal dapat diperoleh puncak keadilan tertinggi karena terjadinya kesepakatan para pihak yang terlibat dalam perkara pidana tersebut yaitu antara pihak pelaku dan korban. Pihak pelaku dan korban diharapkan dapat mencari dan mencapai solusi serta alternatif terbaik untuk menyelesaikan perkara tersebut dengan prinsip win-win solution.

Hukum adat yang merupakan yang merupakan hukum asli Indonesia,sudah lama mengenal prinsip mediasi penal yang diterapkan dalam menyelesaikan kasus-kasus adat yang muncul. Suatu perbuatan hanya akan dianggap delik adat apabila masyarakat setempat berdasarkan kesepakatan menganggap bahwa perbuatan tersebut telah menimbulkan goncangan/ mengganggu keseimbangan kosmis. Begitu pula sanksi/reaksi adat yang diberikan bertujuan untuk mengembalikan keseimbangan kosmis yang terganggu bukan semata-mata untuk menghukum/menjerakan si pelaku. Konsep restitusi atau pengembalian keadaan dengan tujuan untuk mengembalikan keseimbangan kosmis pada hukum adat sejalan dengan hakikat mediasi penal dalam hukum pidana.

Praktek mediasi di Polres Solok mediasi penal antara pelaku dan korban sering diawali dengan pertemuan keluarga korban dan keluarga pelaku diluar lingkungan kantor Polres dengan mediator adalah masyarakat atau ninik mamak/pemamgku adat. Pertemuan pelaku dan korban untuk mediasi penal dapat dilangsungkan di dalam lingkungan Polres 
dan di luar lingkungan Polres. Untuk pertemuan di dalam lingkungan Polres, dilakukan dengan fungsi penyidik sebagai mediator netral, sedangkan pertemuan di luar lingkungan Polres menghadirkan mediator masyarakat dengan kewajiban menyerahkan surat kesepakatan kepada penyidik. Inisiatif Mediasi Penal di Polres Solok biasanya berasal dari Pelaku dan korban yang prisipnya nenerima dengan beberapa persyaratan.

Pada prinsipnya mediasi penal diawali dengan kesepakatan yang dibangun oleh para pihak diluar Polres dengan melibatkan ninik mamak/pemamngku adat, setelah kedua belah pihak antara pelaku dan korban sepakat untuk berdamai maka akan dituangkan dalam surat perjanjian perdamaian, atas dasar surat perjanjian perdamaian tersebut Polres Solok bertindak sebagai mediator netral yang akan menjelaskan kembali isi-isis perjanjian tersebut dan meminta para pihak untuk komitmen dengan perjanjian yang sudah disepakati. Setelah adanya Surat Perdamaian tersebut, penyidik yang menangani perkara akan melakukan koordinasi dengan pejabat yang berwenang di Lingkungan Polres Solok untuk dapat menerima surat tersebut sebagai alasan menghentikan penyidikan. Jika pejabat dimaksud menyetujui, maka penyidik akan mengarahkan korban untuk mencabut laporannya.

Dasar Pertimbangan Penyidik menyelesaikan tindak pidana dengan mediasi penal meliputi pertimbangan dari sisi yuridis dan dari sisi non yuridis. Pertimbangan dari sisi yuridis karena adanya Pasal 18 ayat (1) Undang-Undang Nomor 2 Tahun 2002 tentang Kepolisian Negara Republik Indonesia yang memperbolehkan setiap pejabat Polri mengambil tindakan diskresi sehingga diambilnya tindakan mediasi penal dimaknai sebagai bentuk pengejawantahan tindakan diskresi tersebut. Kemudian, terdapat pula Surat Kapolri Nomor : B/3022/XII/2009/ SDEOPS tentang Penanganan Kasus Melalui Alternative Dispute Resolution. Namun untuk surat kapolri ini, tidak semua penyidik menjadikan hal tersebut sebagai dasar pertimbangan sebab penyidik sudah terwadahi melalui dasar hukum pasal 18 ayat (1) Undang-Undang Nomor 2 Tahun 2002 tentang Kepolisian Negara Republik Indonesia.

Penyelesaian tindak pidana pengrusakan dengan mediasi penal melalui usahausaha membangun komunikasi antara pihakpihak yang berkompeten di dalam komunitas adat, sebut saja mamak kepala suku yang ada dalam kaum Korban dan mamak kepala suku yang ada di pihak pelaku. Kemudian upaya perdamaian yang dilakukan oleh kedua belah pihak dengan menyatakan rasa penyesalan dan permohonan maaf serta mengakui kesalahannya oleh pihak pelaku, pihak korbanpun menerima permohonan maaf yang bersangkutan tanpa ada paksaan dari pihak manapun. Titik simpul kesepakatan kedua belak pihak ini tentunya menjadi dasar kedua 
pihak untuk tidak melanjutkan perkara ini ke ranah hukum.

Peran sentral mediasi perkara ini sebenarnya ada pada pihak pemangku adat yang ada di Nagari Cupak dan Pihak Polri sebagai lembaga formil penegak hukum. Tanpa adanya kata sepakat atau musyawarah antara ninik mamak/pemangku adat sulit kata perdamaian kedua pihak dapat tercapai, pemangku adat merupakan kata pemutus dalam kaum di ranah minang, sehingga keputusan yang sudah diambil oleh mamak kepala waris beserta pemangku adat lainnya, maka menjadi kewajiban bagi anak keponakan untuk mematuhinya, mamak menjadi penjamin dalam pelaksanaan keputusannya tersebut.

Pihak Polri dalam hal ini Polres Solok melalui Polsek Gunung Talang tentunya sebagai lembaga penegak hukum memerlukan kepastian dalam menyelesaikan perkara ini. Ketika perkara ini dianggap penyelesaiannya lebih efektif melalui upaya damai yang dilakukan oleh kedua belah pihak, Polri tentu akan menfasilitasinya dengan beberapa catatan penting. Misalnya, kedua belah pihak membuat perjanjian di atas materai, perjanjian tersebut diketahui dan dikuatkan oleh para pemangku adat yang ada di nagari serta pencabutan laporan secara resmi oleh pihak pelapor disertai alasan pencabutannya.

Adapun konsep yang relevan dalam mediasi penal ini adalah konsep diskresi. Diskresi dalam bahasa Inggris diartikan sebagai suatu kebijaksanaan, keleluasaan Sejalan dengan itu, dalam kamus hukum yang disusun oleh J.C.T Simorangkir diskresi diartikan sebagai kebebasan mengambil keputusan dalam setiap situasi yang dihadapi menurut pendapatnya sendiri. Diskresi adalah wewenang yang diberikan hukum untuk bertindak dalam situasi khusus sesuai dengan penilaian dan kata hati instansi atau petugas itu sendiri.

\section{Kendala Dan Upaya Yang Ditemui Dalam Penyelesaian Perkara Tindak Pidana Pengrusakan Melalui Mediasi Penal pada Sat Reskrim Polres Solok}

Mediasi bukanlah metode baru dalam menyelesaikan sengketa di Indonesia. Substansi mediasi sama dengan mekanisme musyawarah mufakat yang telah dipakai oleh begitu banyak suku yang berbeda adat, bahasa dan cara menyelesaikan sengketa yang tersebar di seluruh Indonesia. Pendekatan melalui jalur mediasi (ADR), pada mulanya termasuk dalam wilayah hukum keperdataan, namun dalam perkembangannya digunakan oleh hukum pidana, hal ini sebagaimana diatur dalam dokumen penunjang Kongres PBB ke-6 Tahun 1995 dalam Dokumen A/CO NF.169/6 menjelaskan dalam perkara-perkara pidana yang mengandung unsur fraud dan whitecollar crime atau apabila terdakwanya korporasi, maka pengadilan seharusnya tidak menjatuhkan pidana, tetapi mencapai suatu hasil yang bermanfaat bagi kepentingan masyarakat secara menyeluruh dan 
mengurangi kemungkinan terjadinya pengulangan.

Dalam praktek mediasi penal yang dilakukan selama ini selain memberikan keadilan retroaktif namun disisi lain sebenarnya membantu Polri dalam menyelesaikan perkara-perkara pidana yang secara subtansial dapat diselesaikan secara kekeluarga melalui instrumen hukum adat atau living law, nilai-nilai yang ada dalam masyarakat. Meskipun demikian mediasi penal sebagai alternatif penyelesaian sengketa dalam perkara pidana namun tidak jarang ditemui berbagai kendala dan hambatan baik secara teknis maupun yuridis.

Sebagai sebuah terobosan, mediasi penal pasti menghadapi hambatan dalam praktik.Apalagi payung hukumnya belum kuat. Beberapa lembaga terkait seperti Mahkamah Agung, Kementerian Pemberdayaan Perempuan dan Perlindungan Anak, Kepolisian, Kejaksaan, Kementerian Hukum dan HAM, serta Kementerian Sosial mencoba membuat aturan bersama yang menampung cara-cara penyelesaian $\mathrm{ABH}$ dengan pendekatan restorative justice.

Hambatan teknis lebih cenderung pada proses yang dilalui oleh para pihak dalam membuat perdamaian atau kesepakatan dan pemahaman para pihak itu sendiri terhadap konsep mediasi penal. Selanjutnya hambatan yuridis lebih menekankan pada aspek legalitas penyeselaian perkara pidana melalui mediasi penal.
Berikut kendala yang dihadapi dalam penyelesaian perkara pidana melalui mediasi penal secara umum adalah:

1. Belum ada pengaturan secara tegas sebagai aspek legalitas yang mengatur mediasi penal dalam penyelesaian perkara pidana. Tanpa ada aturan yang tegas maka dari aspek legalitas masih ada potensi cara-cara penyelesaian perkara pidana dengan mediasi penal akan dilakukan gugatan oleh pihak-pihak terkait. Diskresi yang dimiliki oleh Kepolisian tidak cukup menjadi dasar untuk melakukan mediasi penal dalam perkara pidana.

2. Polri tidak bisa secara penuh berperan sebagai mediator dalam penyelesaian perkara pidana melalui mediasi penal, karena prisipnya Polri menunggu kesepakatan dan keinginan kedua belah pihak untuk berdamai yang difasilitasi oleh ninik mamak dan pemangku adat lainnya yang ada di nagari. Karena keberadaan pemangku adat sangat dihargai dalam kaum dan nagari sehingga perannya sangat urgen dalam menyelesaikan perkara yang terjadi antara anak keponakannya. Sehubungan dengan hal tersebut, perkara-perkara yang sifatnya tidak teralu menimbulkan kerugian fisik, materiil dan moril kadangkala tidak bisa didamaikan karena pihak-pihak yang berperkara tidak ada kata sepakat. Polri pada posisi penegak hukum tentu harus menindaklanjuti laporan tersebut dan tidak pada posisi dominan untuk mendamaikan kedua belah pihak melalui instrumen mediasi penal, dengan kata lain Polri bersikap pasif namun berperan untuk mendamaikan kedua belah pihak (korban dan tersangka).

3. Masih ada sebagian masyarakat berpendapat bahwa semua perkara pidana dapat dilakukan mediasi penal atau usahausaha perdamaian antara pihak-pihak yang berperkara. Misalnya dalam perkara narkoba masih saja ada tokoh-tokoh masyarakat yang mengupayakan kasus tersebut tidak berlanjut ke ranah hukum. 
Berkaiatan dengan berbagai macam kendala ditemui terkait dengan upaya mediasi penal dalam penyelesaian perkara pidana maka perlu dilakukan berbagai usaha untuk mendorong pelaksanaan mediasi penal. Hal ini perlu dilakukan karena mediasi penal dianggap dapat menyelesaikan perkara pidana dengan cara-cara yang efektif, tidak membutuhkan biaya besar, kekeluargaan dan bahkan dapat membantu aparat peengak hukum untuk melakukan kegiatan lain yang lebih produktif, terutama mendorong dan memotivasi tumbuhnya kesadaran hukum masyarakat. Upaya yang mesti dilakukan adalah:

1. Mendorong lembaga-lembaga adat yang ada di nagari beserta tokoh-tokoh adatnya untuk membantu Polri dalam menyelesaikan perkara-perkara pidana yang sumber masalahnya berawal dari masalah tanah warisan, harta pusaka, gelar adat dan sebagainya karena dengan peran lembaga adat dapat lebih efektif dalam penyelesaiannya.

2. Memberikan pemahaman kepada masyarakat bahwa tidak semua perkara pidana yang dapat dilakukan usaha-usaha perdamaian atau mediasi penal atas dasar diskresi yang dimiliki oleh Polri karena Polri sendiri terikat dengan hukum positif.

3. Terhadap perkara yang sudah dilakukan mediasi penal, perlu penekanan dan penegasan oleh Polri pada para pihak bahwa perkara tersebut sudah ditutup dan tidak perlu lagi ditindaklanjuti melalui instrumen hukum pidana. Karena ada juga kecenderungan bahwa perkara pidana yang sudah ada perdamaian kedua belah pihak, namun tiba-tiba dilaporkan kembali oleh pihak korban.

\section{PENUTUP}

Implementasi mediasi penal yang dilakukan oleh Sat Reskirm Polres Solok dalam penyelesaian perkara pidana adalah model victim-offender mediation.

Model ini lebih menekankan pada mediasi antara korban dan pelaku yang melibatkan berbagai pihak yang bertemu. Mediatornya dapat berasal dari pejabat formal, mediator independen, atau kombinasi. Mediasi melibatkan banyak pihak, sebut saja ninik mamak dan pemangku adat setempat dan bahkan Kerapatan Adat Nagari (KAN) juga membantu penyelesaiannya melalui Keputusan KAN Nomor 97/KSA/KAN/ CUPAK-2017.

Kendala yang ditemui dalam mediasi penal pada Polres Solok adalah belum ada pengaturan secara tegas sebagai aspek legalitas yang mengatur mediasi penal dalam penyelesaian perkara pidana, kemudian Polri tidak bisa secara penuh berperan sebagai mediator dalam penyelesaian perkara pidana melalui mediasi penal, karena prisipnya Polri menunggu kesepakatan dan keinginan kedua belah pihak untuk berdamai yang difasilitasi oleh ninik mamak dan pemangku adat lainnya yang ada di nagari serta masih ada sebagian masyarakat berpendapat bahwa semua perkara pidana dapat dilakukan mediasi penal atau usaha-usaha perdamaian antara pihak-pihak yang berperkara. Upaya yang mesti dilakukan adalah mendorong lembaga-lembaga adat yang ada di nagari beserta tokoh-tokoh 
adatnya untuk membantu Polri dalam menyelesaikan perkara-perkara pidana yang sumber masalahnya berawal dari masalah tanah warisan, harta pusaka, gelar adat dan sebagainya.

\section{DAFTAR PUSTAKA}

\section{Buku}

Barda Nawawi Arief, Mediasi Penal: Penyelesaian Perkara di Luar Pengadilan, Pustaka Magister, Semarang, 2008

Djoko Prakoso, Pembaharuan Hukum Pidana Di Indonesia, Liberty, Yogyakarta, 1987.

Khotbul Umam, Penyelesaian Sengketa di Luar Pengadilan, Penerbit Pustaka Yustisia, Yogyakarta, 2010.

Makalah "Mediasi Pidana (Penal Mediation) Dalam Penyelesaian Sengketa/Masalah Perbankan Beraspek Pidana di Luar Pengadilan" dalam "Dialog Interaktif Mediasi Perbankan", Di Bank Indonesia Semarang, 13 Desember 2006.

Simorangkir, dkk, 2002, Kamus Hukum, Sinar Grafika, Jakarta.

\section{Peranturan Undang-Undang}

Undang-Undang Nomor 2 Tahun 2002 tentang Kepolisian Negara Republik Indonesia 